\title{
ANALISIS PENGARUH FAKTOR EKONOMI DAN RELIGIUSITAS TERHADAP PERSEPSI SUPERVISOR DAN MANAJER MENGENAI INDEPENDENSI DEWAN PENGAWAS SYARI'AH (Studi Kasus pada Bank Syari’ah di Indonesia)
}

\author{
Oleh: Ari Kristin $\mathbf{P}^{1}$
}

\begin{abstract}
The objectives of this study are to tests the effects of economics factor (financial association and relationship of business and "fee" dimention) and Religious factor (charitable dimention) to Shari'a Supervisory Board (SSB) independency to prove empirically research done by Karim (1990). The primary data of this received from perception of shari'a banking managers and supervisors in Indonesia. The data were collected by using questionnaires sent to managers and supervisors. Questionnaires were distributed to 385 shari'a banking managers and supervisors and the response rate is 10, 65\%. The data were analyzed by using multiple regression metode. The result of this research indicated that religious factor has positive and significant relationship with SBB independency. It also indicate that financial association and relationship of business has negative relationship and "fee" has positive relationship with SBB but both of them are not significant. This research finding in line with research of Karim (1990).
\end{abstract}

Keywords: Shari'a Supervisory Board (Ssb), Independency, Financial Association And Relationship Of Business, Fee, Religious

\section{PENDAHULUAN}

Kesadaran akan kesejahteraan umat telah menggugah para cendekiawan muslim untuk mencari solusi terbaik dalam praktek perekonomian yang sesuai dengan syariat Islam, salah satunya adalah dengan dibentuknya Bank Syari'ah. Didukung dengan populasi umat Islam yang mayoritas di Indonesia, maka wacana Bank syari'ah mulai bangkit dan diterima dengan baik oleh masyarakat khususnya masyarakat muslim. ${ }^{2}$

Eksisitensi bank syari'ah di Indonesia telah dimulai sejak tahun 1992 dengan diberlakukannya UU No. 7 Tahun 1992 tentang perbankan yang pada saat itu masih menggunakan istilah bank bagi hasil. Kemudian UU tersebut diamandemen menjadi UU No. 10 Tahun 1998 yang secara eksplisit menetapkan bahwa bank dapat beroperasi berdasarkan

\footnotetext{
${ }^{1}$ Dosen Jurusan Ekonomi Islam Fakultas Syari'ah IAIN Walisongo

E-mail:ari_kristin@gmail.com

${ }^{2}$ Prabowo, Tommy, 2000, "Bank Syari'ah: Lahir dari Hasil Diskusi Kesadaran Umat Islam”, Media

Akuntansi, No. 15, November - Desember, hal. 5.
} 
prinsip-prinsip syari'ah. Kemudian, UU No. 23 Tahun 1999 tentang bank Indonesia juga menetapkan bahwa Bank Indonesia dapat melakukan pengendalian moneter berdasarkan prinsip-prinsip syari'ah. Kedua sistem tersebut selanjutnya menjadi dasar hukum bagi keberadaan dual banking system di Indonesia, yaitu adanya dua sistem perbankan (konvensional dan syari'ah) secara berdampingan dalam memberikan pelayanan jasa perbankan bagi masyarakat. ${ }^{3}$

Sejak dikeluarkannya fatwa Majelis Ulama Indonesia (MUI) pada tanggal 23 Desember 2003 yang menyatakan bahwa bunga bank haram hukumnya. Bank syari'ah adalah suatu alternatif lain yang bisa dipilih oleh umat muslim supaya tetap dapat memperoleh ketenangan dan ketentraman bathin karena yakin tidak melakukan hal yang melanggar syari'ah. Supaya nasabah tidak merasa ragu dalam menggunakan fasilitas bank syari'ah, maka bank syari'ah perlu menjaga kemurniannya dari praktek-praktek konvensional. Jangan sampai bank syari'ah melaksanakan praktek-praktek yang melanggar syari'ah dan istilah "bank syari'ah" hanya digunakan sebagai kedok belaka, karena dalam menjalankan usahanya masih banyak ditemukan upaya bank untuk sekedar merubah penampilan formal bank sehingga dapat dikatakan bank syari'ah. ${ }^{4}$

Perkembangan bank Syari'ah yang begitu pesat membawa kekhawatiran tersendiri. Kekhawatiran tersebut berhubungan dengan kemurnian bank syari'ah dari prinsip-prinsip syari'ah. Untuk menjaga kemurnian praktik bank syari'ah maka dibentuklah Dewan Pengawas Syari'ah (DPS). Adanya DPS ini merupakan salah satu hal pokok yang membedakan antara bank konvensional dengan bank syari'ah. Tugas DPS yang utama adalah mengawasi pelaksanaan operasional bank dan produk-produknya supaya tidak menyimpang dari aturan syari'ah. DPS ini dibentuk dengan rekomendasi dari Dewan Syari'ah Nasional (DSN), yang dibentuk sejak tahun 1997 sebagai lembaga syari'ah tertinggi yang mengayomi dan mengawasi operasional kesyari'ahan lembaga-lembaga keuangan syari'ah di Indonesia. ${ }^{5}$

Menyadari pentingnya peran DPS sebagai suatu profesi yang dapat menjadikan masyarakat ataupun nasabah lebih yakin untuk tetap menggunakan jasa bank syari'ah, maka independensi DPS sangat diperlukan dalam melaksanakan tugasnya. Oleh karena DPS merupakan kepercayaan masyarakat, maka anggota DPS dituntut untuk tidak memihak siapapun (independen), bersifat objektif dan jujur. Independensi DPS pada dasarnya bersumber dari kebutuhan untuk memberi kredibilitas bagi suatu laporan operasi bank syari'ah. Kebutuhan ini untuk meningkatkan kepercayaan para pemakai laporan operasional bank (nasabah) supaya mereka yakin bahwa tidak terjadi pelanggaran syari'ah dalam operasional bank syari'ah.

Berdasarkan survey dan penelitian mengenai preferensi masyarakat yang dilakukan oleh Bank Indonesia bekerja sama dengan lembaga penelitian perguruan tinggi ditemukan adanya keraguan masyarakat terhadap kepatuhan syari'ah oleh Bank Syari'ah. Komplain yang sering muncul adalah aspek pemenuhan syari'ah (sharia compliance).

Dalam pokok-pokok hasil penelitian Bank Indonesia yang keenam menyatakan bahwa nasabah yang menggunakan jasa Bank Syari'ah, sebagian memiliki kecenderungan untuk berhenti menjadi nasabah antara lain karena kualitas pelayanan yang kurang baik dan atau

3 Siregar, Mulya, 2002, "Agenda Pengembangan Perbankan Syari'ah dalam Mendukung Sistem Perekonomian yang Tangguh di Indonesia: Evaluasi, Prospek dan Arah Kebijakan”, Simposium Nasional I Sistem Ekonomi Islam, hal .609.

${ }^{4}$ Idat, Dhani Gunawan, "Trend Bank Syari'ah : Penurunan Terhadap Kepatuhan Prinsip Syari'ah", Media Akuntansi, Edisi 33, Mei 2003, hal. 30-31.

${ }^{5}$ Prabowo, Tommy, "Bank Syari'ah: Lahir dari Hasil Diskusi Kesadaran Umat Islam", Media Akuntansi, No. 15, November - Desember 2000, hal. 5. 
keraguan akan konsistensi penerapan prinsip syari'ah. ${ }^{6}$ Kepatuhan dan kesesuaian Bank terhadap prinsip syari'ah sering dipertanyakan oleh para nasabah. Secara Implisit hal tersebut menunjukkan bahwa praktik perbankan syari'ah selama ini tidak memperhatikan prinsipprinsip syari'ah, salah satu penyebabnya adalah pengawasan yang belum optimal. Pengawasan yang tidak optimal ini disebabkan beberapa faktor antara lain tidak tegasnya kualifikasi pemilihan dewan pengawas dan ketidak mandirian anggota dewan pengawas dalam menjalankan fungsinya.

Hasil penelitian Bank Indonesia juga memberikan rekomendasi kebijakan bahwa kualitas pemahaman prinsip-prinsip syari'ah dalam transaksi perbankan sangat vital untuk meningkatkan keyakinan masyarakat akan profesionalisme pengelola. DPS adalah tokoh kunci yang menjamin bahwa kegiatan operasional bank sesuai dengan prinsip syari'ah. Tidak jauh berbeda dengan akuntan publik yang juga merupakan profesi kepercayaan masyarakat umum, DPS juga harus dapat bersikap independen. Independensi di sini mencakup independence in fact dan independence in appearance. Penilaian masyarakat terhadap independensi DPS pada umumnya akan digeneralisasikan sehingga jika masyarakat mempersepsikan bahwa DPS gagal mempertahankan independensinya, maka akan mempengaruhi kepercayaan masyarakat terhadap laporan yang dikeluarkan oleh DPS.

Sedangkan alasan dilakukannya penelitian ini adalah karena BI dalam ringkasan pokok-pokok penelitian "Potensi, Preferensi dan Perilaku Masyarakat Terhadap Bank Syari'ah di Pulau Jawa" menyatakan bahwa nasabah Bank Syari'ah sebagian memiliki kecenderungan untuk berhenti menjadi nasabah antara lain karena keraguan akan konsistensi penerapan prinsip sya'riah. Penelitian ini akan menguji secara empiris mengenai independensi Dewan Pengawas Syari'ah (DPS) yang mengambil kasus pada Bank-Bank Syari'ah. Berdasarkan latar belakang di atas maka masalah dalam penelitian ini adalah adanya keraguan terhadap ketaatan bank syariah terhadap prinsip-prinsip syari'ah. Tujuan dalam penelitian ini adalah untuk menganalisis pengaruh faktor ekonomi terhadap independensi Dewan Pengawas Syari'ah dan untuk menganalisis pengaruh faktor religiusitas terhadap independensi Dewan Pengawas Syari'ah.Hasil dari penelitian diharapkan dapat memberikan manfaat bagi pengelola Bank Syari'ah, Pihak Manajemen, Dewan Syari'ah Nasional (DSN), Dewan Pengawas Syari'ah (DPS) dan pihak lain yang berkepentingan dalam masalah ini.

\section{TINJAUAN TEORITIS}

\section{Perkembangan Bank Syari'ah}

Sejarah berdirinya bank syari'ah dimulai di Mesir seiring dengan kesadaran umat Islam terhadap kesejahteraannya. Ahmad Najjar, seorang guru besar Universitas Al Azhar pendiri sekaligus pemilik Mit Ghamr sebuah lembaga keuangan yang memiliki daerah operasi di sepanjang delta sungai Nil Mesir mulai menggagas pembentukan sistem perbankan syari'ah. Apa yang dilakukan oleh Ahmad Najjar mulai menjadi wacana internasional sejak tahun 1970an, terutama bagi Organisasi Konferensi Islam (OKI). Sampai akhirnya pada sidang mentri keuangan OKI di Jeddah Arab Saudi pada tahun 1975 menyetujui didirikannya Islamic Development Bank (IDB) dengan modal awal 2 miliar Dinar Islam dan semua negara anggota OKI menjadi anggotanya.

\footnotetext{
${ }^{6}$ Bank Indonesia dan Pusat Pengkajian Pembangunan Lembaga Penelitian Undip, "Penelitian Potensi, Preferensi dan Perilaku Masyarakat Terhadap Bank Syari'ah di Jawa Tengah dan DIY", Bank Indonesia Direktorat Penelitian dan Pengaturan Perbankan, 2000, hal. 45.

${ }^{7}$ Syafei, A. Wirman, “Optimalisasi Pengawasan Dewan Syari’ah Nasional”, Media Indonesia, Rabu 11 Desember. 2002
} 
Berdirinya IDB telah memotivasi banyak negara-negara Islam untuk mendirikan lembaga keuangan syari'ah. Pada akhir periode 1970-an dan awal periode 1980-an bank-bank syari'ah bermunculan di Mesir, Sudan, negara-negara Teluk, Pakistan, Iran, Malaysia, Bangladesh serta Turki. Sampai akhirnya didirikan Bank syari'ah pertama di Indonesia, yaitu bank Muamalat Indonesia (BMI) pada tanggal 3 November 1991 di Bogor. ${ }^{8}$ Adanya bank Islam yang sesuai dengan prinsip syari'ah ini memberikan peluang bagi umat Islam yang taat pada ajaran agamanya untuk menggunakan fasilitas bank karena mereka merasa yakin tidak melakukan pelanggaran terhadap syari'ah Islam, terutama yang berhubungan dengan "Riba".

Bank syari'ah adalah suatu sistem perbankan yang didasarkan pada kaidah dan syariat Islam. Operasional bank syari'ah ini berbeda dengan bank konvensional. Perbedaan antara bank syari'ah dan bank konvensional menyangkut aspek legal, struktur organisasi, usaha yang dibiayai, dan lingkungan kerja.Corak yang membedakan Bank Islam adalah bahwa semua transaksi keuangan mereka harus sesuai dengan syari'ah Islam. Tomkins dan Karim (1987) dalam Karim menunjukkan bagaimana Ajaran Islam mempengaruhi perilaku bisnis dan menyoroti perbedaan antara Islam dan Praktek bisnis barat. ${ }^{9}$ Peraturan sosial yang berbeda mengenai perilaku bisnis mengakibatkan perbedaan dalam operasional keuangan organisasi, akuntansinya dan analisa keuangannya. Syariat Islam melarang pembayaran dan penerimaan riba (Quran 2:275-6), perjudian (Quran 5:90), menimbun (Quran 9:34), dan spekulasi (Khatib, 1961; Qureshi, 1976) dalam semua transaksi keuangan. Institusi Islam juga tidak bisa menanam modal dalam perusahaan yang memperdagangkan alkohol, daging babi, dan aktivitas lain yang dipertimbangkan tidak halal dari Perspektif Islam.

Dalam kerangka dasar penyusunan dan penyajian laporan keuangan Bank Syari'ah disebutkan bahwa karakteristik Bank Syari' ah adalah:

1. Prinsip syari'ah Islam dalam pengelolaan harta menekankan pada keseimbangan antara kepentingan individu dan masyarakat.

2. Bank syari'ah ialah bank yang berasaskan, antara lain, pada asas kemitraan, keadilan, transparansi dan universal serta melakukan kegiatan usaha perbankan berdasarkan prinsip syari'ah. Kegiatan bank syari'ah merupakan implementasi dari prinsip ekonomi Islam dengan karakteristik antara lain (1) pelarangan riba, (2) tidak mengenal konsep time-value of money, (3) knsep uang sebagai alat tukar bukan sebagai komoditas, (4) tidak diperkenankan melakukan kegiatan yang bersifat spekulatif, (5) tidak diperkenankan menggunakan dua harga untuk satu barang, dan (6) tidak diperkenankan dua transaksi dalam satu akad.

3. Bank syari'ah beroperasi dengan konsep bagi hasil

4. Bank syari'ah tidak membedakan secara tegas antara sektor moneter dan sektor riil.

5. Bank syari'ah juga dapat menjalankan kegiatan usaha untuk memperoleh imbalan atas jasa perbankan lain yang tidak bertentangan dengan prinsip syari'ah.

6. Suatu transaksi sesuai dengan prinsip syari'ah apabila telah memenuhi seluruh syarat sebagai berikut ini: (a) transaksi tidak mengandung unsur kedzaliman, (b) bukan riba, (c) tidak membahayakan pihak sendiri ataupun pihak lain, (d) tidak ada penipuan (gharar), (e) tidak mengandung materi-materi yang diharamkan dan (f) tidak mengandung unsur judi (maisyir)

Pengawasan bank Syari'ah (termasuk pula pengaturannya) memiliki dua sistem, yaitu pengawasan dari aspek: (1) kondisi keuangan, kepatuhan pada ketentuan perbankan secara umum dan prinsip kehati-hatian bank, dan (2) pemenuhan prinsip syari'ah dalam kegiatan

${ }^{8}$ Afdawaiza, "Isu-isu Kontemporer di sekitar Perbankan Islam (Antisipasi untuk Pengembangan ke Depan)”, Simposium Nasional I Sistem Ekonomi Islam, Yogyakarta, 2002, hal 417.

${ }^{9}$ Karim, Rifaat Ahmed Abdel, 1990, "The Independence of Religious and Eksternal Auditors: The Case of Islamic Bank", JAAAJ, Vol.3 No.3, hal 34-44. 
operasional bank. ${ }^{10}$ Lebih lanjut Harisman menyatakan bahwa pengawasan pada perbankan syari'ah lebih bersifat multilayer yang secara ideal akan terdiri dari sistem pegawasan internal dan sistem pengawasan eksternal.

Sistem pengawasan internal terdiri dari unsur-unsur: RUPS, Dewan Komisaris, Dewan Audit, DPS, Direktur Kepatuhan, dan Internal Shari'ah Reviewer (SKAI). Sedangkan sistem pengawasan eksternal terdiri dari unsur-unsur: BI, Akuntan Publik (termasuk eksternal syari'ah auditor), DSN dan Stakeholder/Masyarakat pengguna jasa. Sistem pengawasan internal lebih bersifat mengatur ke dalam dan dilakukan agar ada mekanisme dan sistem kontrol untuk kepentingan manajemen. Sedangkan pengawasan eksternal pada dasarnya untuk memenuhi kepentingan nasabah dan kepentingan publik secara umum. Peran dan tanggung jawab BI dalam pengawasan ini secara umum hanya pada aspek keuangan, sedangkan pemenuhan prinsip syari'ah adalah tanggung jawab dan kewenangan DSN dengan DPS sebagai perpanjangan tangannya.

Surat keputusan DSN No.Kep-98/MUI/III/2001 tentang susunan pengurus DSN MUI Masa Bhakti 2000 - 2005, antara lain menyebutkan bahwa DSN memberi tugas kepada DPS untuk: (1) melakukan pengawasan secara periodik pada lembaga keuangan syari'ah, (2) mengajukan usul-usul pengembangan lembaga keuangan syari'ah kepada pimpinan lembaga yang bersangkutan dan kepada DSN, (3) melaporkan perkembangan produk dan operasional lembaga keuangan syari'ah yang diawasinya kepada DSN sekurang-kurangnya dua kali dalam satu tahun anggaran, dan (4) merumuskan permasalahan yang memerlukan pembahasan dengan DSN.

\section{Dewan Pengawas Syari'ah (DPS)}

Antonio dan Karim menyatakan bahwa bank syari'ah dapat memiliki struktur yang sama dengan bank konvensional, misalnya dalam hal komisaris dan direksi, tetapi unsur yang sangat membedakan antara bank syari'ah dan bank konvensional adalah keharusan adanya Dewan Pengawas Syari'ah yang bertugas mengawasi operasional bank dan produk-produknya agar sesuai dengan garis-garis syari'ah.

DPS merupakan unit yang hanya dimiliki oleh perusahaan/organisasi yang dijalankan sesuai syari'ah Islam. Laporan DPS untuk meyakinkan bahwa operasi, transaksi, bisnis lembaga keuangan itu dilaksanakan sesuai dengan aturan dan prinsip syari'ah Islam.

DPS didefinisikan sebagai lembaga Independen atau hakim khusus dalam fikih muamalat (fiqh almuamalat). Namun DPS bisa juga anggota diluar fikih tetapi ahli juga didalam bidang lembaga keuangan Islam dalam fikih muamalat. DPS merupakan suatu lembaga keuangan yang berkewajiban mengarahkan, mereview dan mengawasi aktivitas lembaga keuangan agar dapat diyakini bahwa mereka mematuhi aturan dan prinsip syari'ah Islam, fatwa anggota DPS akan mengikat lembaga keuangan Islam.

DPS harus minimal terdiri dari tiga anggota. DPS dapat mencari jasa konsultan yang memiliki keahlian dalam bisnis, ekonomi, hukum, akuntansi dan lain-lain. Anggota DPS tidak boleh berasal dari dewan direksi, anggota pemegang saham lembaga keuangan Islam. Pemberhentian anggota DPS harus melalui rekomendasi dewan direksi dan harus mendapat persetujuan dewan pemegang saham dalam RUPS. ${ }^{11}$

Dibandingkan dengan perbankan konvensional, DPS lebih berkuasa dan lebih berhak dibandingkan dengan Dewan direksi. Dalam banyak kasus, Otoritas DPS memadai untuk

${ }^{10}$ Harisman, "Pelaksanaan Pengawasan Perbankan Syariah di Indonesia", dalam www. Tazkia.com, Kategori Bank Syariah, 28 Oktober 2002.

${ }^{11}$ Harahap, Sofyan S, Auditing dalam Perspektif Islam, Pustaka Quantum, Jakarta, 2002, hal 57. 
eksternal auditor karena anggaran dasar bank ditetapkan atas dasar religius. Karim juga menyatakan bahwa sifat independensi DPS memfokuskan pada kesetiaan institusi terhadap ajaran Islam untuk komitmen pada prinsip-prinsip bisnis yang Islami, sehingga diharapkan tidak tergantung pada tekanan dari manajemen.

DPS menetapkan hal-hal yang harus ditaati oleh bank dalam semua transaksi keuangannya. Briston dan El-Ashker dalam Karim, menyatakan bahwa fungsi DPS, yang pada umumnya dalam artikel asosiasi bank, terdapat dalam tiga area utama: yakni ex ante auditing, ex post auditing dan kalkulasi dan pembayaran Zakat. Disamping itu, fungsi lain yang dinyatakan oleh Briston dan El-Ashker adalah DPS juga dilibatkan dalam kebijakan akuntansi bank. $^{12}$

Bagaimanapun juga akuntan publik dan anggota DPS ditugaskan oleh pemegang saham untuk melaporkan kepada para pemegang saham bank. DPS juga mempunyai hak mengakses sumber informasi dari manapun dan pada akhir tahun fiskal, mengeluarkan laporan khusus yang diterbitkan bersamaan dengan laporan tahunan akuntan publik. Laporan DPS akan meyakinkan pembaca laporan keuangan bank bahwa operasional keuangan bank telah sesuai syariat Islam. Laporan ini dimaksud untuk memberi kredibilitas informasi dalam laporan keuangan dilihat dari perspektif religius. Kedudukan DPS dalam suatu organisasi bank syari'ah biasanya sejajar kedudukannya dengan Dewan Komisaris. Hal ini untuk menjamin efektifitas dari setiap opini yang diberikan oleh Dewan Pengawas Syari'ah.

\section{3. $\quad$ Persepsi Independensi Dewan pengawas Syari'ah (DPS)}

Pengertian persepsi adalah suatu proses yang ditempuh individu untuk mengorganisasikan dan menafsirkan kesan-kesan indera mereka agar memberikan makna bagi lingkungan mereka. Lebih lanjut Robbins menyatakan bahwa individu yang memandang sesuatu yang sama tetapi mempersepsikannya secara berbeda. ${ }^{13}$ Perbedaan persepsi tersebut dipengaruhi oleh faktor-faktor yang membentuk dan kadang memutar balik persepsi yaitu pelaku persepsi (perceiver), obyek atau target yang dipersepsikan dan situasi dimana persepsi itu dilakukan.

Karim (1990) menyatakan bahwa ada sejumlah persamaan mendasar antara peran DPS dan akuntan publik. Keduanya mengeluarkan laporan yang memverifikasi laporan keuangan yang secara wajar hasil operasi organisasi. DPS menjamin apakah aktivitas operasional bank, seperti yang dicerminkan dalam laporan keuangan, adalah sesuai syari'ah sedangkan auditor eksternal mengkonfirmasikan apakah laporan keuangan tersebut adil (fair) tentang posisi keuangan bank dan hasil aktivitasnya. Keduanya DPS dan akuntan publik harus dinilai independen oleh para pemakai laporan supaya kredibilitas laporan yang mereka keluarkan tidak mendapatkan keraguan.

Parwataatmadja dan Antonio (1992) menyatakan bahwa untuk menjaga independensi DPS, maka maka harus diperhatikan hal-hal berikut: (1) Mereka bukan staf bank, dalam arti bahwa mereka tidak tunduk dibawah kekuasaan administratif, (2) Mereka dipilih oleh Rapat Umum Pemegang Saham, (3) Honorarium mereka ditentukan oleh Rapat Umum Pemegang Saham dan (4) DPS mempunyai sistem kerja dan tugas-tugas tertentu seperti halnya Badan Pengawas lainnya.

Dalam penelitian ini yang memepengaruhi independensi DPS adalah factor ekonomi dan religiusitas. Untuk factor ekonomi seperti yang telah disebutkan diatas bahwa ada kemungkinan dari pihak manajemen bank syari'ah untuk memberi penekanan lebih pada aspek ekonomi dari pada aspek religiusitas. Beberapa dimensi ekonomi yang diperkirakan

\footnotetext{
${ }^{12}$ Karim, Rifaat Ahmed Abdel, op.cit. hal 38.

${ }^{13}$ Robbins, Stephen P., Perilaku Organisasi: Konsep, Kontroversi, Aplikasi, Edisi Bahasa Indonesia, Prenhallindo, Jakarta, 2001, hal.104.
} 
dapat merusak independensi DPS yang diambil dari beberapa literatur dan penelitian yang membuktikan bahwa faktor-faktor ini mempengaruhi independensi akuntan publik adalah sebagai berikut: (1) Ikatan kepentingan ekonomi/keuangan dan hubungan usaha dengan pihak manajemen Bank. Auditor dapat kehilangan independensinya apabila mereka mempunyai kepentingan keuangan dan hubungan usaha dengan kliennya. Auditing Standard for Islamic Institution (ASIFIs) No. 1 denga judul "Tujuan dan Prinsip Audit" menyatakan bahwa prinsip umum audit Lembaga Keuangan Syari'ah yang pertama adalah auditor harus memenuhi "Kode etik professi akuntan" yang tidak bertentangan dengan aturan dan prinsip syaria'ah. Jika dianalogikan dengan akuntan publik, maka ikatan keuangan atau hubungan usaha dengan klien yang diperiksa akan menyebabkan rusaknya independensi (2) “Fee". Profesi sebagai anggota DPS akan memperoleh fee dari pekerjaannya tersebut. Yang dimaksudkan dengan DPS "fee" disini adalah pembayaran yang diperoleh anggota DPS sebagai imbalan atas jasa pemeriksaan bank terhadap ketaatan operasional bank terhadap prinsip-prinsip syari'ah yang dilakukannya.

Sedangkan untuk faktor religiusitas, dalam studi keagamaan sering dibedakan antara Religi (agama) dengan Religiusitas. Kata religion/religi berasal dari bahasa Inggris, yang dalam bahasa Indonesia sering disebut dengan agama dan dalam bahasa Arab sering disebut dengan kata addin. Nasir dalam Ghozali menyatakan bahwa agama merupakan sistem yang sudah melembaga dan secara mendasar menjadi norma yang mengikat dalam keseharian dan menjadi pedoman dari sebagian konsep ideal. Ajaran-ajaran agama yang telah difahami dapat menjadi pendorong kehidupan individu sebagai acuan dalam berinteraksi kepada Tuhan, sesama manusia maupun alam sekitarnya. ${ }^{14}$

Sedangkan religiusitas lebih mengarah pada kualitas penghayatan dan sikap hidup seseorang berdasarkan nilai-nilai keagamaan yang diyakininya. Jadi lebih menekankan pada nilai-nilai luhur keagamaan dan cenderung memalingkan diri dari formalisme keagamaan.

Religiusitas dalam Islam bukan hanya terjadi ketika seseorang melakukan ibadah ritual saja, melainkan juga ketika melakukan aktivitas lainnya sehari-hari. Keberagamaan (religiusitas) diwujudkan dalam berbagai sisi kehidupan manusia. Dalam pernyataan pertama etika Islam adalah supaya manusia mempuyai perilaku yang baik mengikuti ajaran Islam bagi mencapai keredhaan Allah. Agama mempunyai pengaruh dalam pembentukan sikap karena agama meletakkan dasar konsep moral dalam diri individu. Pemahaman akan baik dan buruk, garis pemisah antara sesuatu yang boleh dan yang tidak boleh dilakukan, diperoleh dari pemahaman dan pengetahuan terhadap ajaran agama. Islam sebagai agama merupakan konsep yang mengatur kehidupan manusia secara komprehensif dan universal baik dalam hubungan dengan sang pencipta (HabluminAllah) maupun dalam hubungan sesama manusia (Habluminannas). ${ }^{15}$

Menurut Glock dan Stark, ada lima dimensi religiusitas yaitu keyakinan (the ideological dimension, religious belief), peribadatan atau praktik agama (the ritualistic dimension, religious practice), penghayatan (the experiential dimension, religious feeling), pengamalan (the consequentiql dimension, religious effect), dan pengetahuan agama (the intellectual dimension, religious knowledge). Acok dan Suroso membegi Islam menjadi lima aspek yaitu aspek iman, aspek Islam aspek ihsan, aspek ilmu dan aspek amal. Sedangkan Fuad Nashori membagi agama Islam dalam 5 dimensi yaitu dimensi akidah (iman atau

14 Ghozali, Imam, "Pengaruh Religiositas Terhadap Komitmen Organisasi, Keterlibatan Kerja, Kepuasan Kerja dan Produktivitas”, Jurnal Bisnis STRATEGI, Vol. 9, Juli, Th. 2002, VII, hal. 8. 2003. hal 12.

15 Baraba, Achmad, "Prinsip Dasar Operasional Perbankan Syari’ah”, www.geogle/bank syaria.pdf, 
ideologi), dimensi ibadah (ritual), dimensi amal (pengamalan), dimensi ihsan (penghayatan) dan dimensi ilmu (pengetahuan).

\section{Penelitian Terdahulu}

Penelitian terhadap independensi akuntan publik telah banyak dilakukan, beberapa diantaranya telah dilakukan oleh Rifaat Ahmed Abdel Karim (1990), Shockley (1981), Supriyono pada tahun 1988 dalam Supriyono (1995), Retty Novianty dan Indra Wijaya Kusuma (2001), Titik Maryani dan Unti Ludigdo (2002) dan Suyatmini (2002). Penelitian terdahulu disajikan dalam bentuk ringkasan seperti dalam Tabel 1 dibawah ini:

Tabel 1 Ringkasan Penelitian Terdahulu

\begin{tabular}{|c|c|c|c|c|}
\hline No & Penulis & $\begin{array}{c}\text { Variabel yang } \\
\text { digunakan / } \\
\text { Topik }\end{array}$ & Metode & Hasil \\
\hline 1 & $\begin{array}{l}\text { Rifaat } \\
\text { Ahmed } \\
\text { Abdel } \\
\text { Karim } \\
(1990)\end{array}$ & $\begin{array}{l}\text { Mengkaji } \\
\text { independensi } \\
\text { dewan } \\
\text { pengawas } \\
\text { syari'ah dan } \\
\text { akuntan publik } \\
\text { pada bank } \\
\text { Islam } \\
\end{array}$ & $\begin{array}{l}\text { Studi } \\
\text { pustaka }\end{array}$ & $\begin{array}{l}\text { Independensi Dewan Pengawas } \\
\text { syari'ah banyak dipengaruhi oleh } \\
\text { faktor moral sedangkan independensi } \\
\text { akuntan publik sebagian besar } \\
\text { dipengaruhi oleh faktor ekonomi }\end{array}$ \\
\hline 2 & $\begin{array}{l}\text { Shockley } \\
\text { (1981) }\end{array}$ & $\begin{array}{l}\text { Mengkaji } \\
\text { faktor-faktor } \\
\text { yang } \\
\text { mempengaruhi } \\
\text { independensi } \\
\text { penampilan } \\
\text { Akuntan Publik }\end{array}$ & Regresi & $\begin{array}{l}\text { Pemberian jasa konsultasi kepada } \\
\text { klien meningkatkan resiko rusaknya } \\
\text { indepandensi akuntan publik. KAP } \\
\text { kecil mempunyai resiko kehilangan } \\
\text { independensi lebih besar dari pada } \\
\text { KAP yang besar. Sedangkan lamanya } \\
\text { jangka waktu hubungan audit tidak } \\
\text { signifikan mempengaruhi } \\
\text { independensi akuntan publik }\end{array}$ \\
\hline 3 & \begin{tabular}{|c|} 
Supriyono \\
$(1988)$
\end{tabular} & $\begin{array}{l}\text { Mengkaji } \\
\text { faktor-faktor } \\
\text { yang } \\
\text { mempengaruhi } \\
\text { independensi } \\
\text { penampilan } \\
\text { Akuntan Publik }\end{array}$ & Regresi & $\begin{array}{l}\text { Ikatan kepentingan keuangan dan } \\
\text { hubungan usaha dengan klien } 78 \% \text {, } \\
\text { Persaingan antar KAP } 48 \% \text {, } \\
\text { Pemberian jasa lain selain audit } 42 \% \text {, } \\
\text { lamanya penugasan audit } 34 \% \text {, } \\
\text { Ukuran KAP yang kecil } 27 \% \text {, dan } \\
\text { Besarnya fee audit } 8 \% \\
\text { mempengaruhi rusaknya } \\
\text { independensi akuntan public }\end{array}$ \\
\hline 4 & $\begin{array}{l}\text { Retty } \\
\text { Novianty } \\
\text { dan Indra } \\
\text { Wijaya } \\
(2001)\end{array}$ & $\begin{array}{l}\text { Mengkaji } \\
\text { faktor-faktor } \\
\text { yang } \\
\text { mempengaruhi } \\
\text { independensi } \\
\text { penampilan } \\
\text { Akuntan Publik }\end{array}$ & $\begin{array}{l}\text { Chi- } \\
\text { Square } \\
\text { test }\end{array}$ & $\begin{array}{l}\text { Ikatan keuangan dan hubungan usaha } \\
\text { dengan klien signifikan } \\
\text { mempengaruhi independensi } \\
\text { penampilan akuntan publik. } \\
\text { Sedangkan } \\
\text { Faktor-faktor yang tidak } \\
\text { mempengaruhi adalah : Pemberian } \\
\text { jasa lain selain audit, lamanya } \\
\text { penugasan audit, ukuran KAP, } \\
\text { persaingan antar KAP, dan besarnya } \\
\text { auditfee }\end{array}$ \\
\hline
\end{tabular}




\begin{tabular}{|c|c|c|c|c|}
\hline 5 & $\begin{array}{l}\text { Titik } \\
\text { Maryani } \\
\text { dan } \\
\text { Unti } \\
\text { Ludigdo } \\
(2002)\end{array}$ & $\begin{array}{l}\text { Mengkaji } \\
\text { faktor-faktor } \\
\text { yang } \\
\text { mempengaruhi } \\
\text { sikap dan } \\
\text { perilaku etis } \\
\text { akuntan }\end{array}$ & $\begin{array}{c}\text { Statistik } \\
\text { deskriptif }\end{array}$ & $\begin{array}{l}\text { Faktor Religiusitas menepati urutan } \\
\text { pertama yang dominan mempengaruhi } \\
\text { sikap dan perilaku etis akuntan, yaitu } \\
\text { sebesar } 67,46 \%\end{array}$ \\
\hline 6 & $\begin{array}{l}\text { Suyatmini } \\
(2002)\end{array}$ & $\begin{array}{l}\text { Mengkaji } \\
\text { faktor-faktor } \\
\text { yang } \\
\text { mempengaruhi } \\
\text { independensi } \\
\text { penampilan } \\
\text { Akuntan Publik }\end{array}$ & Regresi & $\begin{array}{l}\text { Ikatan keuangan dan hubungan usaha } \\
\text { dengan klien, Pemberian jasa lain } \\
\text { selain audit, lamanya hubungan } \\
\text { audit, Besarnya audit fee, dan } \\
\text { Hubungan social berpengaruh negatif } \\
\text { terhadap independensi akuntan } \\
\text { publik. Sedangkan Persaingan antar } \\
\text { KAP dan Ukuran KAP tidak } \\
\text { mempengaruhi independensi } \\
\text { penampilan akuntan publik. }\end{array}$ \\
\hline
\end{tabular}

\section{Pengembangan Hipotesis}

Beberapa penelitian mengenai independensi akuntan publik telah dilakukan yang diantaranya dipengaruhi oleh faktor ekonomi dan moral. Faktor moral dalam hal ini identik dengan etika dan etika akan terbentuk oleh nilai-nilai dalam diri individu termasuk di dalamnya adalah agama (religi). Apabila dianalogikan dengan akuntan Publik maka independensi DPS juga akan dipengaruhi oleh faktor ekonomi dan moral.

Hipotesis dalam penelitian ini dikembangkan dari Faktor ekonomi yang diwakili oleh dua dimensi yaitu dimensi ikatan kepentingan ekonomi/ keuangan dan hubungan usaha dan dimensi fee. Kedua dimensi faktor ekonomi ini dianalogkan dari independensi akuntan publik yang telah banyak dilakukan penelitiannya dalam bidang akuntansi (auditing) seperti yang telah dikemukakan sebelumnya. Sedangkan faktor religiusitas hanya diwakili oleh satu dimensi yaitu dimensi amal (pengamalan). Pemilihan dimensi amal ini dilakukan karena amalan merupakan kesempurnaan dari keimanan. Sebagaimana definisi iman menurut salaf adalah itiqod dalam hati, diucapkan dengan lisan dan diamalkan dengan perbuatan.

\section{Hubungan Independensi dengan Ikatan kepentingan ekonomi/keuangan dan hubungan usaha dengan pihak manajemen Bank.}

Apabila dianalogkan dengan akuntan publik, maka adanya ikatan kepentingan ekonomi/keuangan dan hubungan usaha antara anggota DPS dengan pihak manajemen bank diperkirakan akan berpengaruh negatif terhadap independensi DPS. Hal ini disebabkan karena ikatan kepentingan ekonomi/keuangan dan hubungan usaha antara DPS dengan pihak manajemen bank akan meningkatkan ketergantungan anggota DPS kepada bank yang bersangkutan secara ekonomi. Maka hipotesis mengenai pengaruh ikatan kepentingan ekonomi/keuangan dan hubungan usaha antara anggota DPS dengan pihak manajemen bank dapat dirumuskan sebagai berikut:

Hipotesis 1: Faktor ekonomi dalam dimensi ikatan kepentingan ekonomi/keuangan dan hubungan usaha antara anggota DPS dengan pihak manajemen bank berpengaruh negatif terhadap independensi DPS. 


\section{Hubungan Independensi dengan DPS "Fee"}

Sebagaimana profesi yang lainnya, profesi sebagai anggota DPS akan memperoleh fee dari pekerjaannya tersebut. Seperti halnya akuntan publik anggota DPS dituntut independen dalam menjalankan tugas profesinya, tidak berpihak pada pihak manajemen bank, karena laporan yang dikeluarkannya akan dimanfaatkan oleh pihak-pihak lain yang membutuhkan. Audit fee berpengaruh secara negatif terhadap independensi akuntan publik. ${ }^{16}$ Jika diaqnalogkan dengan anggota DPS, maka DPS fee yang jumlahnya besar kemungkinan besar akan mengurangi independensi DPS dalam memberikan laporannya. Hal ini disebabkan oleh beberapa alasan, antara lain: (1) DPS akan tergantung pada pihak manajemen sehingga cenderung segan untuk menentang kehendak/keinginan pihak manajemen, (2) jika tidak memberikan laporan yang sesuai dengan keinginan pihak manajemen, anggota DPS merasa khawatir akan kehilangan pekerjaaannya mengingat pendapatan yang diterima relatif besar. Maka hipotesis mengenai pengaruh DPS fee terhadap independensi DPS dapat dirumuskan sebagai berikut:

Hipotesis 2: Faktor ekonomi dalam dimensi DPS "fee" berpengaruh negatif terhadap independensi DPS.

\section{Hubungan Independensi dengan Faktor Religiusitas Dimensi Amal (Pengamalan)}

Amal merupakan puncak aplikasi dari keimanan seseorang. Seorang manusia yang religius akan meyakini adanya pengawasan dari Allah dan meyakini bahwa tidak ada kekuatan lain yang berkuasa selain hanya kekuasaan Allah saja tidak akan tergantung pada apapun termasuk pada orang lain melainkan hanya bergantung pada Allah semata.

Anggota DPS yang mengamalkan ajaran agamanya dengan baik akan meningkatkan independensi anggota DPS karena dia menyadari bahwa tidak ada yang lebih berkuasa kecuali Allah semata dan semua perbuatannya nanti akan dipertanggungjawabkan hanya kepada Allah. Ketaatan anggota DPS terhadap syariat Islam akan mendorongnya untuk tetap mempertahankan independensi anggota DPS.

Dalam hal ini dapat dikatakan bahwa semakin anggota DPS menyadari tanggung jawabnya baik kepada Allah, kepada masyarakat, maupun tanggung jawab terhadap profesinya akan semakin meningkatkan independensi anggota DPS.

Hipotesis 3: Faktor religiusitas dalam dimensi amal (pengamalan) berpengaruh positif terhadap independensi DPS.

Dari uraian dan pengembangan hipotesis diatas maka kerangka pemikiran teoritis mengenai pengaruh faktor ekonomi dan faktor religiusitas terhadap independensi Dewan Pengawas Syari'ah dapat dijelaskan pada gambar 1:

\footnotetext{
${ }^{16}$ Suyatmini, "Studi Empiris Faktor-faktor yang Mempengaruhi Independensi Penampilan Akuntan Publik", Tesis Magister Akuntansi Universitas Diponegoro Semarang, Tidak dipublikasikan, 2002, hal 78.
} 


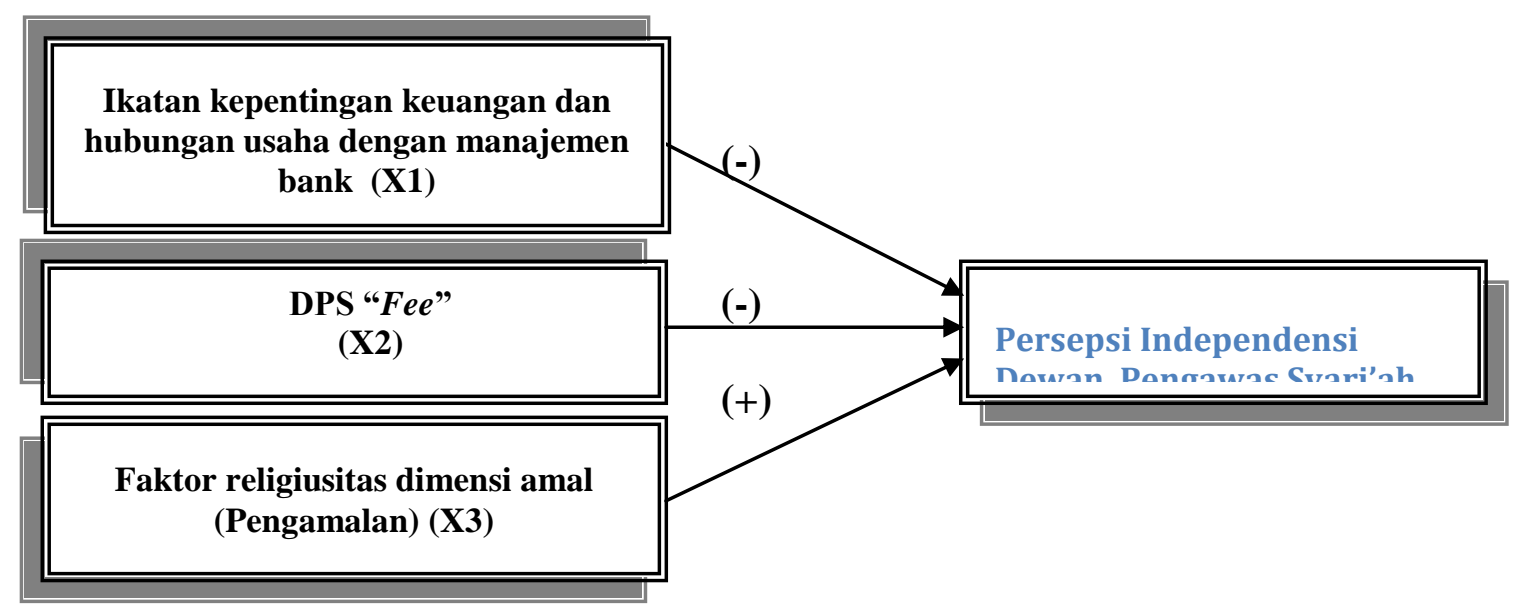

Gambar 1 Kerangka pemikiran teoritis

\section{METODE PENELITIAN}

Jenis data yang dipakai dalam penelitian ini merupakan data subjek, yaitu jenis data penelitian yang berupa opini, sikap, pengalaman atau karakteristik dari seseorang atau kelompok orang yang menjadi subjek penelitian (responden). Sedangkan sumber data yang digunakan dalam penelitian ini adalah data primer yang diperoleh dengan menyebar kuesioner. Data primer adalah data yang bersumber dari jawaban responden atas beberapa pertanyaan mengenai persepsi responden terhadap Ikatan kepentingan ekonomi/keuangan dan hubungan usaha DPS dengan pihak manajemen bank dan DPS "fee" yang merupakan dimensi dari faktor ekonomi, hubungan manusia dengan Allah dan hubungan manusia dengan manusia yang merupakan faktor religiusitas, juga persepsi responden terhadap independensi DPS.

Populasi dalam penelitian ini adalah semua manajer dan supervisor yang menggunakan jasa dan laporan DPS. Sedangkan sampel yang digunakan dalam penelitian ini adalah para manajer dan supervisor pada lembaga perbankan syari'ah baik bank syari'ah murni maupun bank-bank konvensional yang membuka unit bisnis syari'ah dalam kegiatan operasionalnya. Penelitian ini memilih para manajer dan supervisor pada lembaga perbankan syari'ah sebagai responden karena mereka lebih mengetahui tentang DPS sehingga dapat memberikan persepsinya terhadap independensi DPS. Teknik sampling yang digunakan adalah teknik sampling nonprobabilitas, yaitu convenience sampling. Metode convenience sampling ini dipilih karena jumlah populasinya yang belum pasti dan untuk memudahkan peneliti dalam memperoleh data. Jumlah sampel dan populasi penelitian belum diketahui secara pasti dan unit analisis penelitian ini adalah pada individu (manajer dan supervisor pada bank syari'ah) dengan alasan individu tersebut akan mempunyai persepsi yang bervariasi mengenai independensi DPS pada bank syari'ah.

Jumlah responden tidak diketahui secara pasti, oleh karena itu penelitian ini memprediksi jumlah responden dari masing-masing bank syari'ah berdasarkan banyaknya kantor cabang dari bank yang bersangkutan. Masing-masing kantor cabang dikirimkan 5 kuesioner karena masing-masing kantor cabang minimal memiliki 2 manajer dan sisanya diharapkan untuk diisi supervisor ataupun manajernya jika kantor cababng tersebut memiliki lebih dari dua manajer, sedangkan untuk kantor pusat dikirimkan 10 kuesioner karena kantor pusat adalah tempat dimana anggota DPS bekerja sehingga diharapkan lebih banyak supervisor/staff yang dapat memberikan persepsinya terhadap independensi DPS. Kuesioner dikirimkan kepada masing-masing responden baik melalui jasa pos maupun secara personal. 
Adapun definisi operasional dan pengukuran variabel dalam penelitian ini diambil dari teori-teori auditing, terutama yang berkitan dengan independensi akuntan publik dan kode etik akuntan publik yang peneliti coba untuk menerapkannya pada independensi Dewan Pengawas Syari'ah. Masing-masing variabel akan diukur berdasarkan indikator-indikator yang akan dijaring dengan instrumen kuesioner. Pengukuran masing-masing faktor terdiri dari beberapa butir pertanyaan dengan mengunakan skala Likert 10 poin. Responden diminta untuk memilih jawaban yang sesuai mulai dari skala 1 sampai dengan skala 10.

Persepsi Manajer dan Supervisor terhadap Independensi Dewan pengawas Syari'ah. Variabel dependen dalam penelitian ini adalah Persepsi Supervisor dan Manajer terhadap independensi Dewan Pengawas Syari'ah. Persepsi Supervisor dan Manajer terhadap independensi merupakan cara manajer dan supervisor menafsirkan sikap kejujuran DPS mempertimbangkan fakta-fakta dan adanya pertimbangan yang obyektif dalam merumuskan dan menyatakan pendapat.

Faktor Ekonomi. Dalam pengukuran variabel faktor ekonomi ini, peneliti akan menggunakan dua dimensi untuk melihat faktor ekonomi yaitu: (1) Ikatan kepentingan ekonomi/ keuangan dan hubungan usaha dengan pihak manajemen Bank. Ikatan kepentingan ekonomi/keuangan dan hubungan usaha dengan pihak manajemen Bank yang dimaksudkan disini adalah ikatan kepentingan ekonomi/keuangan dan hubungan usaha dengan pihak manajemen bank syari'ah yang dapat merusak independensi DPS dan (2) DPS "fee", Yang dimaksud dengan persepsi terhadap DPS "fee" disini adalah cara pandang manager dan supervisor dalam menafsirkan pembayaran yang diberikan oleh manajemen bank kepada anggota DPS sebagai reward dari hasil kerjanya memberikan laporan atas kepatuhan operasional bank terhadap prinsip-prinsip syari'ah.

Faktor Religiusitas Dimensi Amal (Pengamalan). Religiusitas (keberagamaan) adalah hal-hal yang berhubungan dengan aspek agama yang terkait dengan kehidupan manusia sehari-hari yang bukan hanya terjadi ketika seseorang melakukan ibadah ritual saja, melainkan juga ketika melakukan aktivitas lainnya sehari-hari. Religiusitas ini akan diukur dalam dimensi amal (Pengamalan). Sesungguhnya sejauh mana tingkat religiusitas seseorang itu hanya Allah saja yang mengetahui. Namun demikian, setidaknya alat ukur (skala) dapat dijadikan pedoman untuk mengukur religiusitas seseorang. Para pakar telah mencoba untuk mengetahui tingkat religiusitas seseorang dengan membuat alat ukur atau skala dimensi religi. ${ }^{17}$ Hawari membuat alat ukur (skala) dimensi religi bagi seseorang yang beragama Islam. Butir-butir (items) skala dimensi religi versi Hawari merujuk pada ajaran agama (Islam) berdasarkan kitab suci Al Qur'an dan Al Hadist. ${ }^{18}$

Untuk memberikan gambaran mengenai demografi responden (umur, posisi dalam perbankan syari'ah, lamanya bekerja di perbankan syari'ah dsb) dan deskripsi mengenai variabel-variabel penelitian (Ikatan kepentingan ekonomi/keuangan dan hubungan usaha DPS dengan pihak manajemen bank, DPS " $f e e$ ", pengamalan ajaran agama, dan independensi DPS), peneliti menggunakan tabel distribusi frekuensi absolut yang menunjukkan angka ratarata, median, kisaran, dan standar deviasi.

Kualitas data yang di hasilkan dari penggunaan instrumen penelitian dapat dievaluasi melalui uji reliabilitas dan validitas. Pengujian tersebut dimaksud untuk mengetahui konsistensi dan akurasi data yang dikumpulkan dari penggunaan instrumen. Uji reabilitas (keandalan) dimaksudkan untuk menunjukkan sejauh mana pengukuran itu dapat memberikan

\footnotetext{
${ }^{17}$ Hawari, Dadang, Dimensi Religi Dalam Praktek Psikiatri dan Psikologi, Balai Penerbit FKUI, Jakarta,2002, hal.56.

${ }^{18}$ Hawari, Dadang, Dimensi Religi Dalam Praktek Psikiatri dan Psikologi, Balai Penerbit FKUI, Jakarta,2002, hal 59.
} 
hasil yang relatif tidak berbeda bila dilakukan pengukuran kembali terhadap subjek yang sama di dalam suatu penelitian.

Asumsi klasik diperlukan supaya model regresi yang digunakan dalam penelitian ini dapat dipertanggungjawabkan. Uji asumsi klasik ini terdiri dari: (1) Uji Normalitas. Uji normalitas digunakan untuk mengetahui apakah masing-masing data pada variabel yang diteliti telah terdistribusi secara normal. Uji normalitas yang digunakan dalam penelitian ini menggunakan analisis grafik. Analisis grafik dilakukan dengan melihat melihat grafik normal probability plot, dimana distribusi data dapat dikatakan normal jika garis yang menggambarkan data sesungguhnya mengikuti garis diagonal, (2) Uji multikolenieritas bertujuan untuk menguji apakan ditemukan adanya hubungan yang kuat antara variabel independen. Untuk menguji multikolinearitas dengan melihat signifikansi korelasi antar variabel independen. Jika terdapat korelasi yang signifikan antar variabel independen maka terdapat multikolenieritas (korelasi yang tinggi antar variabel independen). Angka yang disyaratkan adalah hingga mencapai nilai 1 dan nilai VIF tidak lebih dari $10 .{ }^{19}$ dan (3) Uji heterokendastisitas bertujuan untuk menguji apakah dalam model regresi terjadi ketidaksamaan variance dari residual suatu pengamatan ke pengamatan yang lain. Jika variance dari residual satu pengamatan dengan pengamatan lain berbeda maka terjadi heterokendastisitas. Model yang baik adalah model yang homokendastisitas. Ada tidaknya heterokendastisitas dapat dilihat dari grafik plot. Jika hasil grafik menunjukkan pola tertentu, berarti telah terjadi heterokendastisitas. ${ }^{20}$

Untuk menguji hipotesis maka digunakan analisis regresi berganda (multiple regression) dengan bantuan program komputer SPSS 10.00 for Windows. Analisis regresi berganda digunakan untuk melihat pengaruh antar variabel. Analisis regresi berganda dipilih karena teknik ini dapat menyimpulkan secara langsung pengaruh masing-masing variabel independen terhadap persepsinsi independensi DPS sebagai variabel dependen.

Analisis parsial pada masing-masing variabel independen dan dependen digunakan untuk menerima atau menolak $\mathrm{H}_{1}, \mathrm{H}_{2}$, dan $\mathrm{H}_{3}$. Analisis dilakukan secara parsial terhadap masing-masing variabel independen dan dependen untuk melakukan penerimaan atau penolakan terhadap hipotesis yang telah diajukan. Pengujian secara parsial ini bertujuan untuk memastikan apakah variabel independen yang terdapat dalam persamaan tersebut secara individu berpengaruh terhadap nilai variabel dependen. Pengujian ini dilakukan dengan menggunakan uji $t$ atau menggunakan $P_{\text {value. Dalam } u j i} t$ ini hipotesis diterima jika $t$ hitung $>t$ tabel atau $\mathrm{P}_{\text {value }}<0,05$. sedangkan pengujian terhadap pengaruh variabel independen secara bersama-sama dilakukan untuk menerima atau menolak $\mathrm{H}_{4}$, yaitu dengan membandingkan antara $\mathrm{F}_{\text {hitung }}$ dengan $\mathrm{F}_{\text {tabel }}$ pada derajat kebebasan dan tingkat kepercayaan tertentu.

Model analisis regresi berganda ini dapat dirumuskan dengan persamaan berikut:

$$
\mathbf{Y}=\alpha+\beta_{1} X_{1}+\beta_{2} X_{2}+\beta_{3} X_{3}+\varepsilon
$$

\section{Dimana}

$\begin{array}{ll}\mathrm{Y} & : \text { Persepsi Independensi DPS } \\ \alpha & : \text { Konstanta } \\ \beta_{1} & \text { : Koefisien variabel Ikatan kepentingan keuangan dan hubungan usaha dengan } \\ & \text { manajemen bank } \\ \beta_{2} & : \text { Koefisien variabel: "Fee" } \\ \beta_{3} & : \text { Koefisien variabel Faktor Religiusitas Dimensi Amal (Pengamalan) }\end{array}$

${ }^{19}$ Gujarati, D.N., Basic Econometric, $3^{\text {th }}$ Edition, Mc. Graw Hill, Inc. 1995, hal. 113.

${ }^{20}$ Ghozali, Imam, Aplikasi Analisis Multivariate dengan Program SPSS, Badan penerbit Universitas Diponegoro, Semarang, 2001, hal 71. 
$\mathrm{X}_{1} \quad$ : Ikatan kepentingan keuangan dan hubungan usaha dengan manajemen bank

$\mathrm{X}_{2} \quad$ : "Fee"

$\mathrm{X}_{3} \quad$ : Faktor Religiusitas Dimensi Amal (Pengamalan)

$\varepsilon \quad:$ Error

Pengaruh variabel independen terhadap variabel dependen diuji dengan tingkat signifikansi $\mathrm{p}<0,05$. Jika koefisien $\beta_{1}, \beta_{2}$, dan $\beta_{3}$ signifikan berarti Ikatan kepentingan ekonomi/keuangan dan hubungan usaha DPS dengan pihak manajemen bank, DPS "fee" dan pengamalan ajaran agama mempunyai pengaruh terhadap persepsi independensi DPS.

\section{PEMBAHASAN}

Data penelitian dikumpulkan dengan mengirimkan 385 kuisioner kepada para manajer dan supervisor / staff Bank Syariah dan Bank Konvensional yang membuka Unit Usaha Syari'ah di Indonesia. Kuesioner yang kembali 65 buah, 25 kuesioner hilang pada saat pengiriman dan 1 kuesioner tidak dapat diolah karena kurang lengkap, sehingga jumlah kuesioner yang dapat diolah hanya 40 kuesioner. Dari 40 responden dapat dijelaskan karakteristik berdasarkan demografi responden yang dijelaskan pada tabel 2

Tabel 2 Profil 40 Responden Yang Berpartisipasi Dalam Penelitian

\begin{tabular}{|ll|c|c|}
\hline \multirow{3}{*}{ Gender } & : Wanita & Jumlah & Persentase \\
& Pria & 10 & 25 \\
\hline Umur & $: 26-30$ & 30 & 75 \\
& $31-35$ & 3 & 7,5 \\
& $36-40$ & 15 & 37,5 \\
& $41-45$ & 12 & 30 \\
& $46-50$ & 5 & 12,5 \\
& $>51$ & 4 & 10 \\
Instansi & $:$ BMI & 1 & 2,5 \\
& BSM & 7 & 17,5 \\
& BNI Syariah & 6 & 15 \\
& BII Syariah Platinum & 20 & 50 \\
\hline Pendidikan: Diploma & 7 & 17,5 \\
& Sarjana (S1) & 3 & 7,5 \\
& Master (S2) & 6 & 77,5 \\
Jabatan & : Manajer & 24 & 15 \\
& Supervisor & 16 & 60 \\
& & & 40 \\
\hline
\end{tabular}

Sumber : Data primer diolah

Dari tabel 2. di atas, tampak bahwa sebagian besar responden yang berpartisipasi adalah pria yaitu sebanyak $30(75 \%)$. Berdasarkan usia, responden terbesar berusia di antara 31 - 35 tahun $(37,5 \%)$, sedangkan dari tingkat pendidikan responden yang terbesar adalah sarjana (S1) sebesar 77,5 \%. Sebaran responden dilihat dari jabatannya, responden terbanyak adalah manajer sebanyak 24 responden $(60 \%)$ dan sisanya 13 responden $(40 \%)$ menjabat sebagai supervisor Bank yang bersangkutan. 


\section{Statistik Diskriptif}

Statistik variabel penelitian dapat dijelasklan pada tabel 3

Tabel 3 Statistik Deskriptif Variabel Penelitian

\begin{tabular}{|l|l|l|l|l|}
\hline Variabel & Minimal & Maksimal & Mean & $\begin{array}{l}\text { Standar } \\
\text { deviasi }\end{array}$ \\
\hline $\begin{array}{l}\text { Ikatan kepentingan } \\
\text { keuangan dan hub. } \\
\text { usaha dengan }\end{array}$ & 1 & 7,8 & 2,915 & 1,787 \\
manajemen bank & 5,313 & 10 & 4,544 & 2,587 \\
"Fee" & 5 & 10 & 8,4218 & 1,20127 \\
Religiusitas & & & 8 & 1,200673 \\
Persepsi Independensi & & & 8,5406 & \\
DPS & & & 25 & \\
\hline
\end{tabular}

Sumber : Data primer diolah

Berdasarkan tabel 3 diatas, terlihat variabel Ikatan Kepentingan Keuangan dan Hubungan Usaha dengan Pihak Manajemen Bank secara rata-rata adalah 2,915 dengan penyimpangan 1,787. Nilai minimal 1 dan nilai maksimal 7,8 dengan rata-rata 2,915 menunjukkan bahwa adanya ikatan kepentingan keuangan dan hubungan usaha anggota DPS dengan pihak manajemen bank sangat kecil.

Variabel "fee" mempunyai nilai minimal 1 dan nilai maksimal 10 dengan ratarata 4,544 dan penyimpangan 2,587. Nilai ini menunjukkan bahwa rata-rata yang diperoleh DPS menurut persepsi manajer dan supervisor adalah kecil. Sedangkan rata-rata variabel religiusitas sebesar 8,42188 dengan penyimpangan sebesar 1,20127 menunjukkan bahwa responden mempersepsikan religiusitas anggota DPS tinggi. Variabel Persepsi Independensi DPS mempunyai rata-rata 8,540625 dengan penyimpangan sebesar 1,200673 menunjukkan bahwa rata-rata persepsi responden terhadap independensi DPS adalah tinggi.

\section{Uji Kualitas Data}

Uji kualitas data dapat dilakukan melalui uji reliabilitas dan validitas. Uji tersebut masing-masing untuk mengetahui konsistensi dan akurasi data yang dikumpulkan dari penggunaan instrumen. Ada dua prosedur yang dilakukan dalam penelitian ini untuk mengukur reliabilitas dan validitas data, yaitu: (1) Uji reliabilitas dengan melihat koefisien (Cronbach) alpha, (2) Uji validitas dengan melihat Pearson correlation antara score masingmasing item dengan total score dapat dijelaskan pada table 4

Tabel 4 Hasil Uji Reliabilitas

\begin{tabular}{|l|c|}
\hline Variabel & Cronbach's Alpha \\
\hline $\begin{array}{l}\text { Ikatan kepentingan keuangan dan } \\
\text { hub. usaha dengan manajemen bank }\end{array}$ & 0,8541 \\
\hline "Fee" & 0,8512 \\
\hline Faktor Religiusitas & 0,9539 \\
\hline Persepsi Independensi DPS & 0,9504 \\
\hline
\end{tabular}

Sumber : Data primer diolah 
Dari hasil pengolahan data dengan menggunakan SPSS 10.0 diketahui bahwa semua intrumen penelitian reliabel, karena semuanya memiliki cronbach alpha $\geq 0,60$, sedangkan dari Pearson correlation dapat dilihat nilai korelasi Pearson antara intrumen Ikatan kepentingan keuangan dan hubungan usaha dengan manajemen bank (K1.1 s/d K1.5), "Fee" (K2.1 s/d K2.4), Faktor Religiusitas (K3.1 s/d K3.4 dan K3.6 s/d K.3.16) dan Persepsi Independensi DPS (Y1 s/d Y16) valid dengan signifikansi $5 \%$, sedangkan K3.5 valid dengan signifikansi $10 \%$.

\section{Uji Asumsi Klasik}

Pertama, Uji normality. Pengujian distribusi normal dilakukan dengan cara melihat histogram yang membandingkan data observasi dengan distribusi yang mendekati normal. Disamping itu digunakan grafik normal probability plot yang membandingkan distribusi kumulatif dari data sesungguhnya dengan distribusi kumulatif dari distribusi normal. Berdasarkan hasil tampilan dan grafik normal plot dapat disimpulkan bahwa grafik histogram memberikan pola distribusi mendekati normal, sedangkan pada grafik normal probability plot terlihat titik-titik menyebar disekitar garis diagonal, serta penyebarannya mengikuti arah garis diagonal. Kedua grafik ini menunjukan bahwa model regresi layak digunakan karena memenuhi asumsi normalitas.

Kedua. Uji Multikolinieritas . Uji multikolinieritas bertujuan untuk menguji apakah model regresi ditemukan adanya korelasi antar variabel bebas (independen). Deteksi terhadap ada tidaknya multikolinieritas dalam penelitian ini dengan melihat nilai tolerance dan nilai variance inflation factor, suatu model regresi yang bebas dari masalah multikolonieritas apabila mempunyai nilai tolerance lebih dari 0,10 atau $10 \%$ dan nilai variance inflation factor (VIF) kurang dari 10

Hasil perhitungan nilai variance inflaction factor (VIF) juga menunjukan hal yang sama, tidak ada variabel bebas yang memiliki nilai VIF lebih dari 10 (Ghozali, 2001) dapat dijelaskan pada tabel 5. Jadi dapat disimpulkan tidak ada multikolinieritas antar variabel bebas dalam model regresi.

Tabel 5 Nilai Variance Inflaction Factor (Vif)

\begin{tabular}{|l|c|c|}
\hline \multicolumn{1}{|c|}{ MODEL } & TOLERANCE & VIF \\
\hline Ikatan Kepentingan Keuangan dan Hub.Usaha & 0,626 & 1,598 \\
\hline FEE & 0,753 & 1,328 \\
\hline RELIGIUSITAS & 0,682 & 1,466 \\
\hline Dependent variable & & \\
\hline
\end{tabular}

Sumber : Data primer diolah, 2004

\subsubsection{Uji Heteroskedatisitas}

Uji heteroskedatisitas untuk menguji apakah dalam model regresi terjadi ketidaksamaan varian dari residual satu pengamatan kepengamatan yang lain. Untuk mengetahui adanya kondisi heteroskedastisitas pada data penelitian ini maka digunakan grafik scatterplot. Bila grafik tidak membentuk pola tertentu yang menunjukkan bahwa data menyebar secara acak maka dapat disimpulkan bahwa tidak terjadi heterokendastisitas. 


\section{GRAFIK SCATTERPLOT}

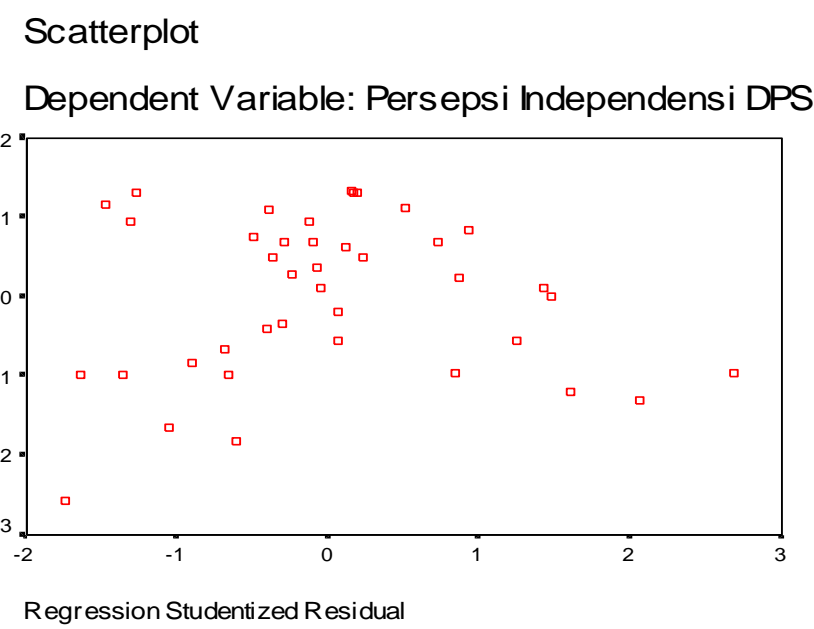

Dari lampiran grafik scatterplot diketahui bahwa tidak ditemukan adanya pola tertentu dalam penyebaran data, jadi dapat disimpulkan tidak terdapat heteroskedastisitas.

\subsection{Pengujian Hipotesis}

Hipotesis dalam penelitian ini diuji dengan menggunakan metode Regresi berganda. Regresi berganda digunakan untuk menguji pengaruh variabel Ikatan kepentingan keuangan dan hubungan usaha dengan manajemen bank, "Fee", dan Faktor Religiusitas terhadap Persepsi Independensi DPS. Metode yang digunakan dalam regresi berganda ini adalah metode enter dengan tingkat signifikansi $(\alpha) 5 \%$. Hasil regresi berganda dapat dilihat pada tabel 4.8. di bawah ini :

HASIL ANALISIS REGRESI BERGANDA

\begin{tabular}{|c|c|c|c|c|}
\hline & $\begin{array}{c}\text { Koefisien } \\
\text { Regresi } \\
\text { Unstandardiz } \\
\text { ed }\end{array}$ & $\begin{array}{c}\text { Koefisien } \\
\text { Regresi } \\
\text { Standardize } \\
\text { d }\end{array}$ & Nilai $-\mathbf{t}$ & Signifikansi \\
\hline Konstanta $(\alpha)$ & 1,397 & & 1,485 & 0,146 \\
\hline $\begin{array}{l}\text { Ikatan Kepentingan } \\
\text { Keuangan dan Hub. } \\
\text { Usaha }\left(\beta_{1}\right)\end{array}$ & - 0,000841 & - 0,013 & - 0,115 & 0,909 \\
\hline "FEE" $\left(\beta_{2}\right)$ & $\mathbf{0 , 0 0 0 2 8 8 3}$ & 0,06 & 0,063 & $\mathbf{0 , 9 5 0}$ \\
\hline RELIGIUSITAS $\left(\boldsymbol{\beta}_{\mathbf{3}}\right)$ & $\mathbf{0 , 8 5 0}$ & $\mathbf{0 , 8 5 0}$ & 8,164 & 0,000 \\
\hline
\end{tabular}

Sumber : Data primer diolah, 2003

Hasil analisis regresi berganda menunjukan adjusted $\mathrm{R}$ square sebesar 0,712 berarti 71,2\% bisa dijelaskan oleh variabel independen (Ikatan Keuangan dan Hubungan Usaha dengan manajemen Bank, "fee" dan religiusitas), sedangkan sisanya 28,8 \% dijelaskan oleh variabel lain.

Nilai $F=33,094$, dengan tingkat signifikansi 0,000 (kurang dari 0,05). Hasil uji statistik tersebut menunjukkan bahwa faktor ekonomi dalam dimensi ikatan kepentingan ekonomi/keuangan dan hubungan usaha, "fee" dan religiusitas secara bersama-sama mempunyai pengaruh yang signifikan terhadap persepsi independensi DPS. Hasil analisis 
statistik menunjukkan bahwa ketiga independen variabel memiliki pengaruh signifikan terhadap dependen variabel. Hal ini menunjukkan bahwa model regresi dapat digunakan untuk memprediksi Persepsi Independensi DPS.

Dari nilai signifikansi masing-masing variabel, ternyata hanya religiusitas yang signifikan menjelaskan atau mempengaruhi Persepsi Independensi DPS. Secara bersama-sama Ikatan kepentingan keuangan dan hubungan usaha dengan pihak manajemen Bank dan " $f e e$ " berpengaruh sangat kecil pada Persepsi Independensi DPS yaitu sebesar -0,013 dan 0,063. Hasil ini berarti faktor ekonomi yang terdiri dari dimensi ikatan kepentingan ekonomi/keuangan dan hubungan usaha antara anggota DPS dengan pihak manajemen bank berpengaruh negatif terhadap independensi DPS, sedangkan "fee" dan faktor religiusitas dimensi pengamalan berpengaruh positif terhadap independensi DPS.

Keseluruhan hasil regresi ini (Pengujian H1, H2, H3, dan H4) hasilnya mendukung penelitian Karim (1990) yang menyatakan bahwa faktor religiusitas lebih dapat mempengaruhi independensi DPS dibandingkan dengan faktor ekonomi. Sedangkan hubungan masing-masing variabel bebas dengan variabel terikatnya ternyata tidak seluruhnya sesuai dengan hipotesis yang dikemukakan. Hasil uji hipotesis menunjukkan bahwa DPS faktor ekonomi (ikatan kepentingan ekonomi/keuangan dan hubungan usaha antara anggota DPS dengan pihak manajemen bank dan DPS "fee") ternyata tidak berpengaruh terhadap independensi anggota DPS.

Dari hasil regresi tersebut di atas, maka dapat dituliskan persamaan regresinya sebagai berikut:

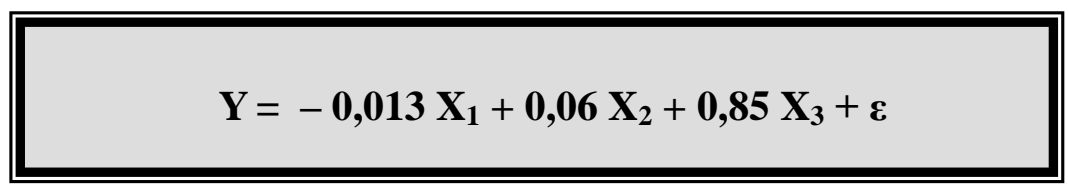

Selanjutnya untuk mengetahui apakah terdapat pengaruh yang signifikan dari masingmasing variabel independen terhadap variabel dependen dapat dianalisis sebagai berikut :

\section{Pengujian Hipotesis 1}

Hipotesis pertama akan menguji apakah faktor ekonomi dalam dimensi ikatan kepentingan ekonomi/keuangan dan hubungan usaha antara anggota DPS dengan pihak manajemen bank berpengaruh negatif terhadap independensi DPS. Berdasarkan perhitungan dengan SPSS 10.00 diperoleh $\mathrm{P}$ value $>0,05(0,909>0,005)$. Hasil uji statistik tersebut menunjukkan bahwa faktor ekonomi dalam dimensi ikatan kepentingan ekonomi/keuangan dan hubungan usaha antara anggota DPS dengan pihak manajemen bank tidak signifikan dalam mempengaruhi independensi DPS, sedangkan hubungan antara faktor ekonomi dalam dimensi ikatan kepentingan ekonomi/keuangan dan hubungan usaha antara anggota DPS dengan pihak manajemen bank dengan independensi DPS adalah negatif. Hubungan negatif ini sesuai dengan hipotesis yang telah dikemukakan sebelumnya (H1). Berdasarkan hasil tersebut maka hipotesis pertama ditolak, karena hasil analisis statistik menunjukkan bahwa hubungan tersebut tidak signifikan.

\section{Pengujian Hipotesis 2}

Hipotesis kedua akan menguji pengaruh faktor ekonomi dalam dimensi DPS "fee" terhadap independensi DPS. Berdasarkan perhitungan dengan SPSS 10.00 diperoleh nilai $\mathrm{P}_{\text {Value }}>0,05(0,950>0,005)$. Hasil pengujian regresi pada hipotesis kedua menunjukkan bahwa faktor ekonomi dalam dimensi DPS "fee" tidak signifikan dalam mempengaruhi independensi DPS, sedangkan hubungan antara faktor ekonomi dalam dimensi DPS "fee" dengan independensi DPS adalah positif. Arah hubungan dari hasil pengujian ini tidak sesuai 
dengan hipotesis yang ingin diuji. Hipotesis kedua yang menyatakan bahwa faktor ekonomi dalam dimensi DPS "fee" berpengaruh negatif terhadap independensi DPS. Hasil pengujian yang tidak sesuai dengan hipotesis yang dikemukakan ini dapat dijelaskan dengan alasan bahwa "fee" yang diterima anggota DPS didasarkan pada profesionalitasnya dan karena anggota DPS telah dipercaya oleh masyarakat maka manajemen bank berani memberikan "fee" yang tinggi untuk menjaga kepercayaan masyarakat terhadap kinerja banknya. "Fee" yang diterima anggota DPS berpengaruh positif terhadap independensinya karena "fee" yang diterima bisa jadi didasarkan pada kepercayaan masyarakat terhadapnya, sehingga semakin besar fee yang diterima semakin besar pula kepercayaan masyarakat terhadap anggota DPS dan anggota DPS harus menjaga kepercayaan itu dengan meningkatkan independensinya.

Hasil regresi hipotesis pertama dan kedua ini mendukung penelitian Karim (1990) yang menyatakan bahwa faktor ekonomi, dalam hal ini dimensi ikatan kepentingan ekonomi/keuangan dan hubungan usaha antara anggota DPS dengan pihak manajemen bank dan DPS "fee" tidak signifikan mempengaruhi independensi DPS. Hasil yang tidak signifikan ini menunjukkan bahwa dalam melakukan tugasnya anggota DPS tidak dipengaruhi oleh faktor ekonomi, dalam hal ini adalah dimensi ikatan kepentingan ekonomi/keuangan dan hubungan usaha antara anggota DPS dengan pihak manajemen bank. Anggota DPS lebih mengutamakan hukum Islam (syari'ah) dibandingkan dengan hilangnya pendapatan ekonomi.

\section{Pengujian Hipotesis 3}

Hipotesis ketiga adalah menguji pengaruh faktor religiusitas dalam dimensi amal (pengamalan) terhadap independensi DPS. Berdasarkan perhitungan dengan SPSS 10.00

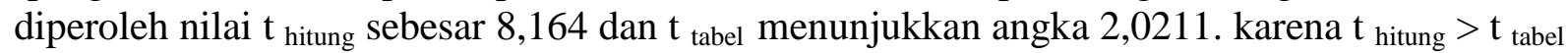
$(8,164>2,0211)$ dan $\mathrm{P}_{\text {value }}<0,05(0,000<0,05)$. Hasil dari analisis regresi menunjukkan bahwa faktor religiusitas dimensi pengamalan signifikan dalam mempengaruhi independensi DPS dan menunjukkan adanya hubungan yang positif. Hubungan positif ini menunjukkan bahwa semakin tinggi tingkat religiusitas anggota DPS dalam dimensi pengamalannya maka semakin tinggi pula tingkat independensinya.

Hasil ini sesuai dengan hipotesis ketiga dan mendukung penelitian Karim (1990) yang menyatakan bahwa independensi DPS dipengaruhi oleh faktor religiusitas dalam hal ini dimensi amal (pengamalan).

Dari nilai signifikansi masing-masing variabel, ternyata hanya religiusitas yang signifikan menjelaskan atau mempengaruhi Persepsi Independensi DPS. Secara bersama-sama Ikatan kepentingan keuangan dan hubungan usaha dengan pihak manajemen Bank dan "fee" berpengaruh sangat kecil pada Persepsi Independensi DPS yaitu sebesar -0,013 dan 0,063. Hasil ini berarti faktor ekonomi yang terdiri dari dimensi ikatan kepentingan ekonomi/keuangan dan hubungan usaha antara anggota DPS dengan pihak manajemen bank berpengaruh negatif terhadap independensi DPS, sedangkan "fee" dan faktor religiusitas dimensi pengamalan berpengaruh positif terhadap independensi DPS.

Keseluruhan hasil regresi ini (Pengujian H1, H2, H3, dan H4) hasilnya mendukung penelitian Karim (1990) yang menyatakan bahwa faktor religiusitas lebih dapat mempengaruhi independensi DPS dibandingkan dengan faktor ekonomi. Sedangkan hubungan masing-masing variabel bebas dengan variabel terikatnya ternyata tidak seluruhnya sesuai dengan hipotesis yang dikemukakan. Hasil uji hipotesis menunjukkan bahwa DPS faktor ekonomi (ikatan kepentingan ekonomi/keuangan dan hubungan usaha antara anggota DPS dengan pihak manajemen bank dan DPS "fee") ternyata tidak berpengaruh terhadap independensi anggota DPS. 


\section{KESIMPULAN DAN KETERBATASAN}

\subsection{Kesimpulan}

Hipotesis pertama menunjukkan hasil yang tidak signifikan dengan arah negatif. Hal ini menunjukkan bahwa ikatan kepentingan ekonomi/keuangan dan hubungan usaha tidak mempengaruhi independensi DPS. Hipotesis kedua menunjukkan hasil yang tidak signifikan dengan arah hubungan positif. Arah hubungan yang positif ini tidak sesuai dengan hipotesis yang dikemukakan. Penjelasan mengenai adanya perbedaan antara arah hubungan dalam hipotesis dan hasil yang diperoleh adalah "fee" yang diterima oleh anggota DPS didasarkan pada kepercayaan masyarakat terhadap profesionalisme anggota DPS tersebut sehingga semakin besar "fee" yang didapatkan DPS menuntut DPS akan meningkatkan independensinya. Hipotesis ketiga dapat diterima karena analisis statistik menunjukkan hasil yang signifikan. Secara bersama-sama (simultan) ikatan kepentingan ekonomi/keuangan dan hubungan usaha, "fee", dan faktor religiusitas dalam dimensi amal (pengamalan) berpengaruh terhadap independensi DPS. Hal ini dapat dilihat dari uji F yang menunjukkan hasil yang signifikan. Hasil pengujian menunjukkan bahwa faktor ekonomi tidak signifikan mempengaruhi independensi DPS, sedangkan faktor religiusitas mempengaruhi independensi DPS.

\subsection{Keterbatasan}

Penelitian ini memiliki keterbatasan-keterbatasan yang kemungkinan dapat menimbulkan gangguan terhadap hasil penelitian. Keterbatasan dalam penelitian ini antara lain:

1. Data yang dianalisis dalam penelitian ini menggunakan instrumen yang mendasarkan pada persepsi jawaban responden. Hal ini akan menimbulkan masalah jika persepsi responden berbeda dengan keadaan sesungguhnya.

2. Penelitian ini hanya menerapkan metode survei kuesioner, peneliti tidak melakukan wawancara atau terlibat langsung dalam akitivitas perusahaan, sehingga kesimpulan yang diambil hanya berdasarkan pada data yang dikumpulkan melalui penggunaan instrumen tertulis (kuesioner).

3. Dalam penelitian ini jumlah responden yang ikut berpartisipasi masih sangat terbatas sehingga hasil penelitian tidak maksimal.

4. Dalam penelitian ini tidak dilakukan uji non respon bias karena sebagian besar kuesioner yang kembali adalah hasil dari pengiriman secara langsung (tidak melalui mail survey) oleh peneliti.[e] 


\section{DAFTAR PUSTAKA}

Afdawaiza, 2002, "Isu-isu Kontemporer di sekitar Perbankan Islam (Antisipasi untuk Pengembangan ke Depan)”, Simposium Nasional I Sistem Ekonomi Islam, p.407 423, Yogyakarta.

Anshari, Endang Saifuddin, 1981, Ilmu, Filsafat dan Agama, Bina Ilmu, Surabaya.

Ashar, Samsul, Prospek Ekonomi Syariah 2004, Mengembangkan Bank Syari'ah Tidak Cukup dengan Fatwa, www.sinarharapan.co.id/ekonomi/keuangan /2004/ 0105/ keul.html-30k,

Antonio, Muhammad Syafi'i, 1999, Bank Syari'ah Wacana Ulama dan Cendekiawan, Tazkia Institute, Jakarta. ,2000, Bank Syari'ah Suatu Pengenalan Umum, Tazkia Institute, Jakarta.

Jakarta. 1999, Bank Syari'ah bagi Bankir dan Praktisi Keuangan, Tazkia Institute, , 2001, Bank Syari'ah dari Teori ke Praktik, Gema Insani Press, Jakarta.

Bank Indonesia, 2000, "Ringkasan Pokok-pokok Hasil Penelitian "Potensi, Preferensidan Perilaku Masyarakat Terhadap Bank Syari'ah di Pulau Jawa'”, Bank Indonesia Direktorat Penelitian dan Pengaturan Perbankan.

Bank Indonesia dan Pusat Pengkajian Pembangunan Lembaga Penelitian Undip, 2000, "Penelitiann Potensi, Preferensi dan Perilaku Masyarakat Terhadap Bank Syari'ah di Jawa Tengah dan DIY", Bank Indonesia Direktorat Penelitian dan Pengaturan Perbankan.

Baraba, Achmad, 2003, "Prinsip Dasar Operasional Perbankan Syari'ah”, www.geogle/bank syaria.pdf - Similar pages

Chapra, Umer, 2000, The Future of Economics, an Islamic Perspectives, The Islamic Fondation, London.

Departemen Agama, 1986, Al-Quran dan Terjemahan, Jakarta.

Deraf, "Bab Enam: Sumbangan Etika Islam kepada Pembangunan MPPB(Masyarakat Perniagaan dan Perindustrian Bumiputra)", vlib.unitarklj1.edu.my/staffpublications/datuk/ ETIKMPPB.pdf-Similar pages

Ghozali, Imam, 2001, Aplikasi Analisis Multivariate dengan Program SPSS, Badan penerbit Universitas Diponegoro, Semarang.

, 2002, "Pengaruh Religiositas Terhadap Komitmen Organisasi, Keterlibatan Kerja, Kepuasan Kerja dan Produktivitas", Jurnal Bisnis STRATEGI, Vol. 9, Juli, Th. VII, p. 1-11

Gujarati, D.N., 1995, Basic Econometric, $3^{\text {th }}$ Edition, Mc. Graw Hill, Inc.

Hair, J.F., Anderson, R.E. \& Black, W.C., 1998, Multivariate Analisys $5^{\text {th }}$ ed., Printice Hall International, Inc.

Hanafi, Syafiq Mahmadah dan Sobirin Achmad, 2002, "Relevansi Ajaran Agama dalam Aktifitas Ekonomi (Studi Komparatif antara Ajaran Islam dan Kapitalisme)", Simposium Nasional I Sistem Ekonomi Islam, p.235 - 254, Yogyakarta. 
Harahap, Sofyan S, 2002, Auditing dalam Perspektif Islam, Pustaka Quantum, Jakarta. , 2003, "Menilai Perkembangan Penerapan Akuntansi Syari’ah", Media Akuntansi, Edisi 33, Mei, p. $49-60$.

Harisman, 2002, "Pelaksanaan Pengawasan Perbankan Syariah di Indonesia", dalam www. Tazkia.com, Kategori Bank Syariah, 28 Oktober.

Hermawan, Sigit, 2002, "Peranan Akuntansi Syari'ah dalam Memberikan Landasan yang Kuat Terhadap Praktek Perbankan Syari'ah”, IKTISADIA, Vol. 2, No. 2, p. 97 -196.

Hawari, Dadang, 2002, Dimensi Religi Dalam Praktek Psikiatri dan Psikologi, Balai Penerbit FKUI, Jakarta.

IAI, 2002, Kerangka Dasar Penyusunan dan penyajian Laporan Keuangan Bank Syari'ah, IAI, Jakarta.

IAI, 2002, Pernyataan Standar Akuntansi Keuangan Akuntansi Perbankan Syari'ah (PSAK No. 59), IAI, Jakarta.

Ibrahim bin Muhammad Al Buraikan,1997, Pengantar Study Aqidah As-Sunnah wa AlJama'ah, Pustaka Amanah, Jakarta.

Idat, Dhani Gunawan, 2003, "Trend Bank Syari'ah : Penurunan Terhadap Kepatuhan Prinsip Syari’ah”, Media Akuntansi, Edisi 33, Mei, p. 30-31.

, 2002, "Perbankan Syariah Indonesia Menuju Milenium Baru: Suatu Tinjauan Pengembangan, Pengawasan dan Prospek", Tim Peneliti dan Pengembangan bank Syari'ah Direktorat Penelitian dan Pengembangan Perbankan, p. 1 - 15.

Indriantoro, Nur dan Bambang Supomo, 1999, Metodologi Penelitian Bisnis, BPFE, Edisi Pertama, yogyakarta.

Karim, Rifaat Ahmed Abdel, 1990, "The Independence of Religious and Eksternal Auditors: The Case of Islamic Bank", JAAAJ, Vol.3 No.3, p: 34-44.

Khoirunissa, Delta, 2002, "Preferensi Masyarakat terhadap Bank Syari'ah (Studi Kasus Bank Muamalat Indonesia dan Bank BNI Syari'ah)", Simposium Nasional I Sistem Ekonomi Islam, p.127 - 161, Yogyakarta.

Lee Chi-Wen Jevons dan Gu Zhaoyang, 1998, "Low Balling, Legal Liability and Auditor Independence", The Accounting Review, Vol. 73 No. 4, p. 533 - 555.

Maryani, Titik dan Unti Ludigo, 2003, "Survey atas faktor-faktor yang mempengaruhi Sikap dan Perilaku Etis Akuntan", www.fe.unibraw.ac.id/tema/Vol-II-1/ Maryani-LudigdoSurvey-atas-Faktor-Faktor-yang-mempengaruhi.pdf - Similar pages

Mayangsari, Sekar, 2003, "Pengaruh Keahlian Audit dan Independensi terhadap Pendapat Audit”, Jurnal Riset Akuntansi Indonesia, Vol.6 No.1, Hal : 1-22, Edisi Januari.

Mulyadi dan Kanaka Puradiredja, 1998, Auditing, Edisi Kelima,Salemba Empat, Jakarta.

Nashori, Fuad,1998, Mengembangkan Kreativitas dalam Prespektif Psikologi Islam, Pustaka Pelajar, Yogyakarta.

Novianty, Retty dan Indra Wijaya Kusuma, 2001, "Analisis faktor-faktor yang mempengaruhi independensi penampilan Akuntan Publik", JAAI, Vol.5 No.1, Edisi Juni. 
Parwataatmadja, Karnaen dan Muhammad Syafi'i Antonio, 1992, Apa dan Bagaimana Bank Islam, Dana Bhakti Wakaf, Yogyakarta.

Philip Gerrard dan J. Barton Cunningham, 1997, "Islamic banking: a study in Singapore", International Journal of Bank Marketing, p.204-216.

Prabowo, Tommy, 2000, "Bank Syari'ah: Lahir dari Hasil Diskusi Kesadaran Umat Islam”, Media Akuntansi, No. 15, November - Desember, p. 5 - 6.

2000, “Menjaga Kemurnian Bank Syari'ah", Media Akuntansi, No. 15, November - Desember, p. 16 - 17.

Qardawi, Yusuf, 2001, Peran Nilai dan Moral dalam Perekonomian Islam, Robbani Press, Jakarta.

Rahman, Afzalur, 1996, Doktrin Ekonomi Islam Jilid 4 (menganai sistem moneter, bank dan asuransi tanpa bunga, serta standar moneter internasional), PT. Dana Bhakti Wakaf, Yogyakarta.

Razak, Nasruddin, 1996, Dienul Islam, Cetakan ke 13, Al Ma'arif, Bandung.

Rick Antle, 1984, “Auditor Independence”, Journal of Accounting Research, Vol. 22 No. 1, Spring, p. 1-20.

Robbins, Stephen P., 2001. Perilaku Organisasi: Konsep, Kontroversi, Aplikasi, Edisi Bahasa Indonesia, Prenhallindo, Jakarta.

Sabiq, Sayid, 1999, AQIDAH ISLAM, Cetakan XI, Penerbit cv. Diponegoro, Bandung.

Samad Abdus and Dr M. Kabir Hassan, 1999, "The Performance of Malaysian Islamic Bank During 1984-1997: An Exploratory Study”, International Journal of Islamic Financial Services, Vol. 1 No.3, p. 3 - 11.

Sarker Mohammed Abdul Awwal, 1999, "Islamic Banking In Bangladesh: Performance, Problems \& Prospects", International Journal of Islamic Financial Services Vol. 1 No.3, p. 12-28.

Siregar, Mulya, 2002, “Agenda Pengembangan Perbankan Syari’ah dalam Mendukung Sistem Perekonomian yang Tangguh di Indonesia: Evaluasi, Prospek dan Arah Kebijakan”, Simposium Nasional I Sistem Ekonomi Islam, p.597 - 619, Yogyakarta.

Sjahdeini, Sutan Romy, 1999, Perbankan Islam dan Kedudukannya dalam Tata Hukum Perbankan Indonesia, Grafiti, Jakarta.

Sudjana, 1992, Statistika untuk Ekonomi dan Niaga, Transito, Bandung.

Suharto, Harry, 2000, “Hadirnya Bank Syari'ah di Indonesia”, Media Akuntansi, No. 15, November - Desember, p. 7 - 8.

Supriyono, 1995, "Pemeriksaan Akuntan : Faktor-faktor yang mempengaruhi Independensi Penampilan Akuntan Publik, suatu hasil penelitian empiris di Indonesia, BPFE, Yogyakarta.

Sriyanto, 2000, "Bank Syari'ah dan Kemurniannya", Media Akuntansi, No. 15, November Desember, p. 4. 
Suyatmini, 2002, "Studi Empiris Faktor-faktor yang Mempengaruhi Independensi Penampilan Akuntan Publik”, Tesis Magister Akuntansi Universitas Diponegoro Semarang, Tidak dipublikasikan.

Syafei, A. Wirman, 2002, “Optimalisasi Pengawasan Dewan Syari'ah Nasional”, Media Indonesia, Rabu 11 Desember.

Yafie, Ali, 2000, “Umat Masih Awam dengan Bank Syari'ah", Media Akuntansi, Edisi November-Desember, VII, p. 15.

Yusanto, Muhammad Ismail, 2002, "Menyoroti Kebijakan Perbankan Syari'ah dalam Konteks Mencari Solusi Alternatif Fundamental Krisis Moneter", Simposium Nasional I Sistem Ekonomi Islam, p.535 - 544, Yogyakarta. 